\title{
Al-Madãris
}

VOL. 2, NO. 2, 2021

E-ISSN: 2745-9950

https://journal.staijamitar.ac.id/index.php/almadaris

\section{MENINGKATKAN AKTIVITAS DAN HASIL BELAJAR MATEMATIKA MELALUI PENGGUNAAN STRATEGI PEMBELAJARAN JIGSA $W$ PADA MATERI SEGIEMPAT DAN SEGITIGA}

\author{
Maryati \\ MTsN 2 Bireun \\ martimatang76@gmail.com
}

\begin{abstract}
This research was conducted at MTsN 2 Bireuen, Central Aceh Regency, Aceh Province. In this study, the research subjects were selected by conducting random sampling by means of a lottery (Syahrum, 2009), first preparing as many pieces of paper as there were, then the pieces of paper were put into a box and taken at random, one of the papers was taken as the research sample. The paper taken is for Class VII-2 Semester 2 which contains 22 people. The object of this research is the application of jigsaw learning strategies to improve students' mathematics learning outcomes on the subject of quadrilaterals and triangles. The model in this research is Classroom Action Research (CAR), which uses Kemmis and Mc's CAR model. Taggart. This research has stages in the form of a cycle. The results of the study of the jigsaw learning strategy in mathematics subjects Class VII-2 MTsN 2 Bireuen can be said that the increase in student learning outcomes. This increase can be seen from the average value of the class has increased. This can be shown from the results of the evaluation that has been carried out to increase student learning outcomes which were originally the average value of 57.73 before the action and the first cycle increased to 69.09. While in the second cycle the increase in learning outcomes to 79.77 . This shows that $86.36 \%$ of students are successful in learning mathematics by using jigsaw learning strategies.
\end{abstract}

Keywords: Improving Activities, Mathematics Learning Outcomes, Jigsaw Learning Strategies, Quadrilaterals and Triangles 


\section{A. Pendahuluan}

Matematika merupakan salah satu pelajaran yang ada dalam pendidikan dasar atau menengah, karena sarana berfikir ilmiah dan memberikan sumbangan yang besar pada semua ilmu. Oleh karena besarnya pengaruh matematika, maka kualitas pengajaran matematika di setiap pendidikan perlu mendapatkan perhatian. Kualitas pengajaran dapat di lihat dari tinggi rendahnya hasil belajar siswa. Dalam Pengajaran matematika guru seharusnya tidak mendominasi kelas dan pengajaran terpusat pada anak. Agar siswa aktif, gembira dan senang matematika. Hal ini di lakukan untuk menghilangkan anggapan bahwa matematika merupakan pelajaran yang sulit, tidak menyenangkan. Guru menghadapi kesulitan dalam pengajaran bagaimana dalam menyelesaikan masalah dengan baik, dilain pihak siswa menghadapi kesulitan bagaimana menyelesaikan masalah yang diberikan guru, berbagai kesulitan ini muncul antara lain karena mencari jawaban di pandang sebagai satu-satunya. tujuan yang ingin dicapai. Karena hanya terfokus dengan jawaban, anak seringkali salah dalam memilih teknik penyelesaian yang sesuai (Suherman, 2003).

Menurut Slameto, dalam pembelajaran seorang guru berperan sebagai fasilitator dan motivator bagi peserta didik. Peran guru sebagai motivator adalah memberi motivasi kepada siswa agar melakukan kegiatan belajar dengan kehendak sendiri sesuai dengan tujuan belajar yang akan dicapai, sedangkan guru sebagai fasilitator adalah memfasilitasi siswa agar dapat belajar dengan mengembangkan potensi yang dimiliki siswa. Guru sebagai pendidik harus bertanggung jawab terhadap hasil belajar siswa dan pengetahuan siswa terkait dengan materi yang telah dipelajari (Slameto, 2010).

Belajar matematika berbeda dengan belajar bidang lain yang biasa dipelajari dengan menghafal saja. Pelajaran matematika selain menghafal juga pemahaman, ketelitian, dan latihan-latihan secara teratur. Belajar metematika sangat dibutuhkan untuk menanam konsep matematika pada siswa dalam mengaplikasikannya dalam kehidupan sehari-hari. Matematika diajarkan bukan hanya untuk mengetahui dan memahami apa yang terkandung dalam matematika itu sendiri. Tetapi matematika diajarkan pada dasarnya untuk membantu melatih pola pikir siswa. Agar dapat memecahkan masalah dengan kritis, logis, cepat tepat. Pembelajaran pendidikan sekolah, upaya meningkatkan kualitas pendidikan terus dilakukan. Para pelajar memerlukan matematika untuk memenuhi kebutuhan praktis dan memecahkan masalah dalam kehidupan sehari-hari, misal dapat berhitung, dapat menghitung isi dan berat, dapat mengumpulkan mengelola, menyajikan dan menafsirkan data, dapat menggunakan kalkulator dan komputer. Selain itu agar mampu mengikuti pelajar matematika lebih lanjut, untuk membantu memahami bidang studi lain seperti fisika, kimia, arsitektur, farmasi, geografi, ekonomi, dan sebaginya, dan agar para siswa dapat berfikir logis, kritis, dan praktis, serta bersikap positif dan berjiwa kreatif.

Dalam pembelajaran matematika di MTsN 2 Bireuen, peneliti mengetahui bahwa rendahnya motivasi belajar siswa pada materi segiempat dan segitiga dan rendahnya hasil belajar siswa. Hal ini dapat dilihat dari rata-rata persentase kondisi awal masih rendah. Hasil yang diperoleh dari tes awal pra tindakan 
dengan nilai-rata-rata sebesar 54,42 dimana ada 6 siswa (23.08\%) dari 26 siswa yang mencapai ketuntasan belajar sedangkan 20 siswa lainnya (76.92\%) belum tuntas sesuai dengan Kriteria Ketuntasan Minimal (KKM) yaitu 270 . Kondisi seperti ini tentu sangat tidak diharapkan dalam proses belajar mengajar

Berdasarkan permasalahan di atas penulis tertarik untuk membuat suasana pembelajaran matematika yang menyenangkan dan mudah untuk dipahami. Peneliti menerapkan salah satu stategi pembelajaran strategi pembelajaran Jigsaw. Peneliti menggunakan strategi pembelajaran Jigsaw ini agar siswa lebih mengambil peran dalam kegiatan pembelajaran serta siswa mempunyai tanggung jawab sebagai ahli untuk menjelaskan kepada teman yang lain. Peneliti juga ingin siswa lebih bisa mengeluarkan ide atau gagasan yang dimiliki saat berada dalam diskusi kelompok. Selain itu membiasakan siswa untuk bertanya pada teman atau guru jika mengalami kesulitan. Strategi pembelajaran Jigsaw ini merupakan pembelajaran kooperatif dimana dalam proses pembelajarannya siswa di bagi menjadi beberapa kelompok-kelompok kecil dan setiap anggota kelompok diberikan materi yang berbeda-beda. Disini siswa tidak hanya dituntut untuk mempelajari materi yang diberikan, tetapi mereka juga harus siap memberikan dan mengajarkan materi tersebut pada anggota kelompoknya yang lain.

Matematika sebagai bahan ajar yang objeknya berupa fakta, konsep, operasi, dan prinsip yang kesemuanya adalah bentuk abstrak. Matematika yang memiliki penalaran deduktif yang berkenaan dengan ide-ide abstrak dan simbolsimbol yang tersusun secara hirarki serta bersifat deduktif aksiomatik, sehingga belajar matematika merupakan kegiatan mental tinggi. Oleh karena itu, belajar matematika memerlukan beberapa kegiatan mental seperti melakukan abstraksi, klasifikasi, dan generalisasi. Mengabstraksi berarti memahami kesamaan dari berbagai objek yang berbeda, mengklasifikasi berarti memahami pengelompokan dari berbagai objek berdasarkan pengetahuan yang dikembangkan melalui contoh-contoh. Menggeneralisasi berarti mengambil kesimpulan berdasarkan contoh-contoh.

\section{B. Review Literatur}

\section{Hasil Belajar Matematika}

Belajar merupakan suatu proses usaha yang dilakukan seseorang untuk memperoleh suatu perubahan tingkah laku yang baru secara keseluruhan sebagai hasil pengalamannya sendiri dalam interaksi dalam lingkungan (Slameto, 2003). Hasil belajar Menurut Sudjana (2002), adalah kemampuan-kemampuan yang dimliki siswa setelah ia menerima pengalaman belajarnya. Sedangkan menurut Syamsuddin (1996), hasil belajar adalah wujud perubahan tingkah laku yang bersifat fungsional, struktural, material, substansial dan behavioral.

Hasil belajar menurut Abdurrahman (1999), adalah kemampuan yang diperoleh anak setelah melalui kegiatan belajar. Hasil belajar juga dipaandang sebagai keluaran dari suatu sistem pemprosesan berbagai masukan yang berupa informasi. Menurut Bloom dalam Suparno (2001), ada 3 ranah (domain) hasil belajar yaitu kognitif, afektif dan psikomotor. Ketiga ranah tersebut menjadi objek penilaian hasil belajar. 
Dari beberapa pendapat di atas dapat diambil maknanya bahwa hasil belajar matematika merupakan perubahan tingkah laku siswa setelah kegiatan belajar matematika yang meliputi aspek kognitif, afektif, dan psikomotor. Kemampuan berupa aspek kognitif dapat dilihat dari kemampuan siswa menyelesaikan soal-soal yang diberikan, kemampuan aspek afektif dapat dilihat dari kemampuan siswa bekerjasama dengan setiap anggota kelompok, selanjutnya kemampuan siswa dalam bertanya, memberikan penjelasan merupakan kemampuan yang dapat dilihat dari aspek psikomotor.

Menurut Trianto (2009), pembelajaaran koopertif model jigsaw adalah salah satu model pembelajaran yang dalam pelaksanaannya suatu kelas terbagi dalam kelompok - kelompok heterogen terdiri atas 5 atau 6 orang peserta didik. Materi pembelajaran di siapkan dan dibagikan kepada peserta didik dalam bentuk teks. Setiap anggota kelompok bertanggung jawab mempelajari sub pokok bahasan tertentu. Peserta didik yang mendapat tanggung jawab yang sama, berkumpul dalam satu kelompok untuk mendiskusikan sub pokok bahasan tertentu. Kelompok ini disebut kelompok ahli, selanjutnya anggota kelompok ahli kembali ke kelompok asal dan menyampaikan materi yang telah dibahasnya secara bergantian.

\section{Strategi Pembelajaran Jigsaw}

Jigsaw pertama kali dikembangkan dan diujicobakan oleh Elliot Aronson dan teman-teman di Universitas Texas, dan kemudian diadaptasi oleh Slavin dan teman-teman di Universitas John Hopkins. (dalam Traianto, 2010). Strategi Jigsaw merupakan teknik pembelajaran kooperatif di mana siswa, bukan guru, yang memiliki tanggung jawab lebih besar dalam melaksanakan pembelajaran. Guru di sini hanya sebagai fasilitator dalam proses pembelajaran. Tujuan dari Jigsaw ini adalah mengembangkan kerja tim, ketrampilan belajar kooperatif, dan menguasai pengetahuan secara mendalam yang tidak mungkin diperoleh apabila mereka mencoba untuk mempelajari semua materi sendirian.

Metode jigsaw adalah teknik pembelajaran kooperatif di mana siswa, bukan guru, yang memiliki tanggung jawab lebih besar dalam melaksanakan pembelajaran. Tujuan dari jigsaw ini adalah mengembangkan kerja tim, ketrampilan belajar kooperatif, dan menguasai pengetahuan secara mendalam yang tidak mungkin diperoleh apabila mereka mencoba untuk mempelajari semua materi sendirian.

Setiap siswa yang ada di "kelompok awal" mengkhususkan diri pada satu bagian dari sebuah unit pembelajaran. Para siswa kemudian bertemu dengan anggota kelompok lain yang ditugaskan untuk mengerjakan bagian yang lain, dan setelah menguasai materi lainnya ini mereka akan pulang ke kelompok awal mereka dan menginformasikan materi tersebut ke anggota lainnya.

Semua siswa dalam "kelompok awal" telah membaca materi yang sama dan mereka bertemu serta mendiskusikannya untuk memastikan pemahaman. Mereka kemudian berpindah ke "kelompok jigsaw" - dimana anggotanya berasal dari kelompok lain yang telah membaca bagian tugas yang berbeda. Dalam kelompok-kelompok ini mereka berbagi pengetahuan dengan anggota kelompok lain dan mempelajari materi-materi yang baru. 
Pada strategi pembelajaran Jigsaw, terdapat kelompok asal dan kelompok ahli. Kelompok asal yaitu kelompok induk siswa yang beranggotakan siswa dengan kemampuan, asal, dan latar belakang keluarga yang beragam. Kelompok asal merupakan gabungan dari beberapa ahli. Kelompok ahli yaitu kelompok siswa yang terdiri dari anggota kelompok asal yang berbeda yang ditugaskan untuk mempelajari dan mendalami topik tertentu dan menyelesaikan tugas-tugas yang berhubungan dengan topiknya untuk kemudian dijelaskan kepada anggota kelompok asal. Dengan menerapkan strategi pembelajaran jigsaw maka seorang peserta didik akan selalu terlibat secara langsung dalam pembelajaran, sehingga dengan keterlibatan ini materi yang dibahas akan selalu teringat dalam pemikirannya dan konsep yang harus dikuasai peserta didik akan mudah diterimanya hal ini sesuai dengan prinsip learning by doing yang menytakan bahwa pembelajaran akan cepat dikuasai peserta didik dengan peserta didik tersebut ikut aktif dalam pembelajaran.

Secara grafis pemikiran yang dilakukan oleh peneliti dapat digambarkan dengan bentuk diagram sebagai berikut:

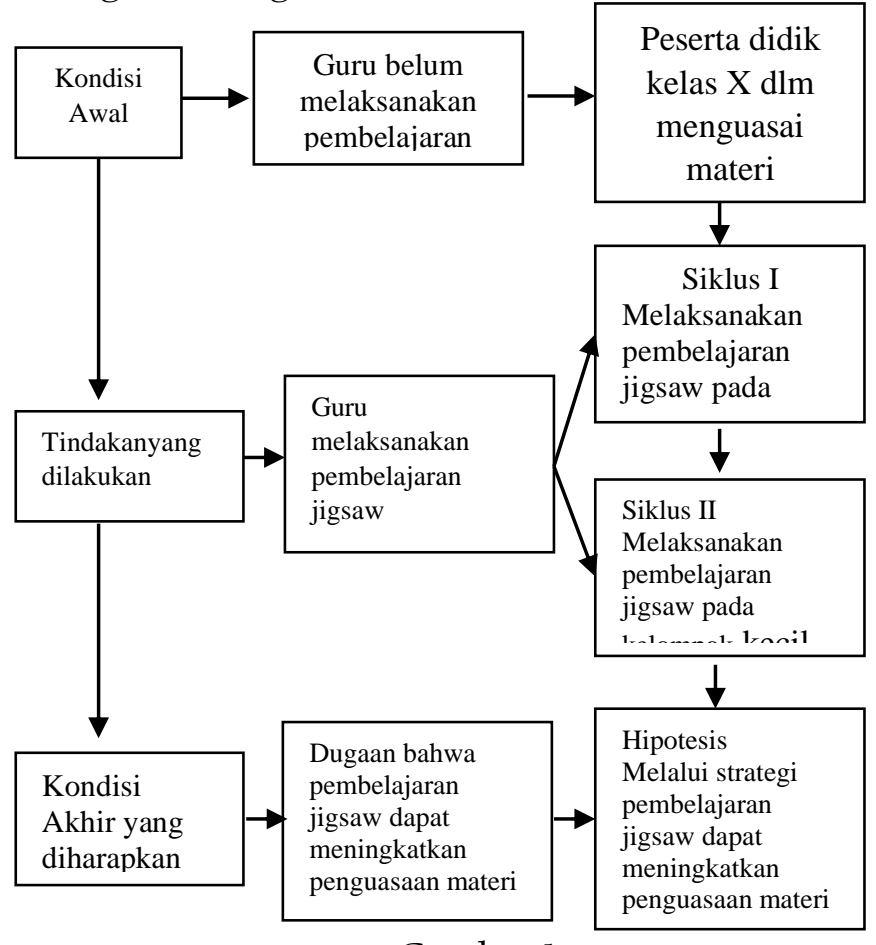

Gambar 1

Diagram kerangka berfikir

\section{Metodelogi}

Penelitian ini dilakukan di MTsN 2 Bireuen Kabupaten Aceh Tengah Provinsi Aceh. Dalam penelitian ini subyek penelitian dipilih dengan melakukan random sampling dengan cara undian (Syahrum, 2009), pertama peneliti menyiapkan potongan kertas sebanyak kelas yang ada, kemudian potongan kertas dimasukkan ke dalam sebuah kotak dan diambil secara acak, salah satu kertas yang terambil akan menjadi sampel penelitian. Kertas yang diambil adalah untuk Kelas VII-2 Semester 2 yang berjumlah 22 orang. Obyek penelitian ini 
adalah penerapan strategi pembelajaran jigsaw untuk meningkatkan hasil belajar matematika siswa pada pokok bahasan segiempat dan segitiga.

Model dalam penelitian ini adalah Penelitian Tindakan Kelas (PTK), yang menggunakan model PTK Kemmis dan Mc. Taggart. Penelitian ini memiliki tahapan berupa siklus. Model PTK kemmis dan Mc. Taggart menjelaskan bahwa dalam satu siklus terdiri dari empat komponen yang dimulai dengan rencana, tindakan, pengamatan, refleksi. Setelah satu siklus diimplementasikan khususnya sesudah adanya refleksi, kemudian diikuti dengan adanya perencanaan ulang yang dilaksanakan dalam bentuk siklus tersendiri, demikian seterusnya atau dengan beberapa kali siklus.

\section{Tahap-tahap dalam penelitian ini dijelaskan sebagai berikut:}

1. Tahap perencanaan tindakan

Perencanaan tindakan mencakup semua langkah tindakan secara rinci, mulai dari materi ajar, rencana pembelajaran yang mencakup strategi yang digunakan, instrumen observasi/evaluasi, dipersiapkan dengan matang pada tahap perencanaan ini.

2. Tahap pelaksanaan tindakan

Setelah perencanaan tindakan disusun, maka tahap ini adalah implementasi (pelaksanaan) dari rencana yang telah dibuat. Tahap ini berlangsung di dalam kelas. Pemberian tindakan dilakukan dengan proses belajar mengajar. Pada tahap ini peneliti akan bertindak sebagai guru untuk menyampaikan materi dan pada akhir pembelajaran diberikan latihan kepada siswa untuk melihat hasil yang telah dicapai melalui pemberian tindakan.

3. Tahap pengamatan

Observasi ini dilakukan pada saat berlangsungnya proses pembelajaran. Observasi yang dilakukan merupakan pengamatan terhadap seluruh kegiatan dan perubahan yang terjadi pada saat dilakukannya tindakan.

4. Tahap refleksi

Tahap ini merupakan tahap untuk memproses data yang diperoleh dari pengamatan, serta mengambil kesimpulan dari langkah perbaikan yang telah dilakukan.

Instrumen yang digunakan dalam pengumpulan data adalah tes, wawancara dan observasi.

a) Tes adalah suatu alat atau prosedur yang sistematis dan objektif, untuk memperoleh data-data atau keterangan-keterangan yang diinginkan tentang seseorang, dengan cara yang cepat dan tepat (Arikunto, 2003: 32).

b) Wawancara dilakukan untuk memperoleh data atau informasi yang berkaitan dengan sikap, pendapat, atau wawasan yang lebih rinci.

c) Observasi dilakukan untuk mengumpulkan, mengolah, dan menyajikan informasi secara cermat sehingga dapat diandalkan untuk dapat mengambil keputusan terhadap tindakan berikutnya. 
Teknik analisis data pada penelitian ini disajikan dengan beberapa tahapan yakni:

1. Reduksi Data

Tahapan ini dilakukan dengan menyeleksi dan menata data yang telah diperoleh. Pada tahap ini, peneliti dapat melihat kesalahan jawaban siswa dalam menyelesaikan soal dan mengetahui letak kesulitan yang dialami siswa dalam memahami materi pelajaran.

2. Penyajian Data

Data kesalahan siswa dalam menjawab soal-soal Segiempat dan segitiga yang telah direduksi sebelumnya disajikan dalam bentuk paparan data kesalahan siswa, dan ditentukan jenis kesulitan siswa.

3. Penarikan Kesimpulan

Kesimpulan diperoleh berdasarkan hasil tindakan penelitian yang telah dilakukan, selanjutnya kesimpulan yang diambil merupakan pedoman bagi pelaksanaan siklus berikutnya. Dalam kesimpulan diperoleh jawaban atas permasalahan yang dialami siswa pada awal pelaksanaan tindakan. Kemudian gambaran pesentase kemampuan siswa dapat dideskripsikan.

4. Menganalisis hasil observasi

Dari observasi yang telah dilakukan, dilakukan penganalisaan dengan menggunakan rumus:

$$
\mathrm{P}_{\mathrm{i}}=\frac{\text { Jumlah seluruh aspek yang diamati }}{\text { Banyaknya aspek yang diamati }} \text {...........................................(Pers. 1) }
$$

Dimana: $\mathrm{P}_{\mathrm{i}}=$ hasil pengamatan pada pertemuan ke-i

Kriteria rata-rata penilaian observsi adalah:

$$
\begin{aligned}
& 0-1,1=\text { Sangat Kurang } \\
& 1,2-2,1=\text { Kurang } \\
& 2,2-3,1=\text { Baik } \\
& 3,2-4,0=\text { Sangat Baik }
\end{aligned}
$$

Pembelajaran dikategorikan efektif jika hasil observasi menunjukkan bahwa pembelajaran termasuk dalam kriteria baik atau sangat baik.

5. Menghitung tingkat penguasaan siswa

\section{Hasil Penelitian}

Pada tahap ini, untuk mengetahui permasalahan dilakukan dengan memberikan tes awal kepada subyek penelitian yaitu Kelas VII-2 MTsN 2 Bireuen yang berjumlah 22 orang. Tes awal ini bertujuan untuk mengetahui kemampuan awal siswa, dan kesulitan-kesulitan yang dialami siswa dalam menyelesaikan soal-soal segiempat dan segi tiga.

\section{Pelaksanaan Siklus I}

\section{a. Tahap Perencanaan}

Sesuai dengan permasalahan yang ditemukan di atas maka dirancang alternatif pemecahan masalah yang juga merupakan perencanaan tindakan, yaitu: (a) guru merencanakan skenario pembelajaran dengan strategi pembelajaran jigsaw; (b) daftar nilai, data keadaan kelas dan hasil pembelajaran pra siklus; (c) 
lembar observasi peserta didik untuk mengamati aktivitas belajar peserta didik ketika mengikuti proses pembelajaran; (d) lembar observasi guru untuk mengamati apakah guru sudah melaksanakan pembelajaran sesuai RPP; (e) lembar soal dan lembar jawab untuk diskusi bagi peserta didik; (f) susunan kelompok belajar secara heterogen sebanyak empat kelompok disetiap kelompok terdiri 5 peserta didik; (f) alat evaluasi yang terdiri dari soal esai untuk melihat keberhasilan siswa dalam menguasai materi.

\section{b. Tahap Pelaksanaan}

Pembelajaran dimulai dengan menarik perhatian siswa, peneliti memberikan motivasi dengan mengajukan pertanyaan yang menantang dan apersepsi dengan mengingatkan materi yang lalu yaitu menyebut mengenai unsur-unsur dan sifat-sifat pada persegi panjang, persegi, segitiga, trapesium, jajar genjang, belah ketupat dan layang-layang. Peneliti juga memberitahukan tujuan pembelajaran pada siswa dan metode pembelajaran yang akan dipakai dalam proses pembelajaran yaitu dengan menerapkan strategi pembelajaran jigsaw.

\section{c. Tahap Observasi}

1. Observasi Aktivitas Guru pada siklus I

Hasil pengamatan terhadap aktivitas guru (peneliti) pada siklus I dapat dilihat pada tebel di bawah ini.

Tabel l. Observasi aktivitas Guru Siklus I

\begin{tabular}{|c|c|c|c|c|}
\hline NO & Aspek Yang Diamati & RPP & RPP & Rata- \\
\hline 1. & \multicolumn{4}{|l|}{ Pendahuluan: } \\
\hline & $\begin{array}{l}\text { a. Kemampuan memotivasi siswa/ mengkomunikasikan } \\
\text { tujuan pembelajaran }\end{array}$ & 4 & 5 & 4.5 \\
\hline & $\begin{array}{l}\text { b. Kemampuan menghubungkan pelajaran saat itu } \\
\text { dengan pelajaran sebelumnya atau membahas PR }\end{array}$ & 4 & 4 & 4 \\
\hline & $\begin{array}{l}\text { c. Kemampuan menginformasikan langkah-langkah } \\
\text { pembelajaran yang digunakan }\end{array}$ & 4 & 5 & 4,5 \\
\hline 2. & \multicolumn{4}{|l|}{ Kegiatan Inti: } \\
\hline & a. Kemampuan menjelaskan materi & 5 & 5 & 5 \\
\hline & $\begin{array}{l}\text { b. Kemampuan mengarahkan siswa untuk bekerja sama } \\
\text { dalam kelompok menemukan jawaban soal, dengan } \\
\text { memberikan bantuan terbatas }\end{array}$ & 4 & 4 & 4 \\
\hline
\end{tabular}




\begin{tabular}{|c|c|c|c|c|}
\hline & $\begin{array}{l}\text { c. Kemampuan cara mengamati cara siswa } \\
\text { menyelesaikan soal/masalah }\end{array}$ & 4 & 5 & 4,5 \\
\hline & $\begin{array}{l}\text { d. Kemampuan mengoptimalkan interaksi siswa dalam } \\
\text { bekerja }\end{array}$ & 4 & 4 & 4 \\
\hline & $\begin{array}{l}\text { e. Kemampuan memimpin diskusi kelas/menguasai } \\
\text { kelas }\end{array}$ & 4 & 4 & 4 \\
\hline & 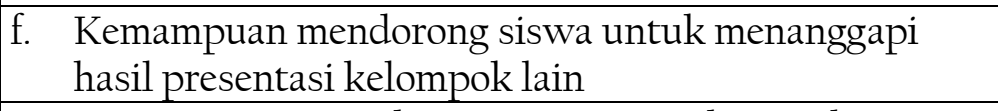 & 4 & 5 & 4,5 \\
\hline & $\begin{array}{l}\text { g. Kemampuan mendorong siswa untuk mau bertanya, } \\
\text { mengeluarkan pendapat atau menjawab pertanyaan. }\end{array}$ & 4 & 4 & 4 \\
\hline & h. Kemampuan menghargai pendapat berbagai siswa & 4 & 4 & 4 \\
\hline & i. Kemampuan mengajukan dan menjawab pertanyaan & 4 & 4 & 4 \\
\hline \multirow[t]{4}{*}{3.} & \multicolumn{4}{|l|}{ Penutup: } \\
\hline & $\begin{array}{l}\text { a. Kemampuan mengarahkan siswa untuk menemukan } \\
\begin{array}{l}\text { sendiri dan menarik kesimpulan } \\
\text { tentangkonsep/prinsip/defenisi/teorema/rumus/prose } \\
\text { dur matematika }\end{array}\end{array}$ & 4 & 5 & 4,5 \\
\hline & $\begin{array}{l}\text { b. Kemampuan menegaskan hal-hal penting intisari } \\
\text { berkaitan dengan pembelajaran }\end{array}$ & 4 & 4 & 4 \\
\hline & $\begin{array}{l}\text { c. Kemampuan menyampaikan judul sub materi } \\
\text { berikutnya/memberikan PR kepada siswa/menutup } \\
\text { Pelajaran }\end{array}$ & 4 & 5 & 4,5 \\
\hline 4. & Kemampuan Mengelola Kelas & 4 & 4 & 4 \\
\hline \multirow[t]{3}{*}{5.} & \multicolumn{4}{|l|}{ Suasana Kelas } \\
\hline & a. Antusias siswa & 4 & 4 & 4 \\
\hline & b. Antusias Guru & 5 & 5 & 5 \\
\hline & Rata-rata Keseluruhan & \multicolumn{3}{|c|}{4,27} \\
\hline
\end{tabular}

Berdasarkan tabel hasil observasi dilapangan nampak bahwa pada kegiatan pendahuluan masih terdapat aspek yang belum muncul seperti kemampuan memotivasi siswa/mengkomunikasi tujuan pembelajaran rata-rata yang diperoleh adalah 4,5. Pada pertemuan pertama dan kedua aspek yang belum sempurna muncul yaitu kemampuan menghubungan antara materi yang akan dipelajari dengan materi sebelumnya. Untuk aspek kemampuan menginformasikan langkah-langkah pembelajaran pada pertemuan pertama belum sempurna, sedangkan pada pertemuan kedua aspek tersebut sudah muncul sempurna sehingga nilai rata-ratanya adalah 4,5.

\section{Observasi Aktivitas Siswa Siklus I}

Pada tahap observasi aktivitas siswa, observer melakukan pengamatan menggunakan lembar observasi yang telah disiapkan. Hasil observasi aktivitas siswa pada siklus I diuraikankan pada tabel di bawah ini. 
Tabel 2 Observasi Aktivitas Siswa Siklus I

\begin{tabular}{|c|c|c|c|c|c|}
\hline \multirow{2}{*}{$\begin{array}{l}\text { Aspek Pengamatan } \\
\text { Aktivitas Siswa }\end{array}$} & \multirow{2}{*}{$\begin{array}{c}\text { RPP } \\
\text { I }\end{array}$} & \multirow{2}{*}{$\begin{array}{l}\text { RPP } \\
\text { II }\end{array}$} & \multirow{2}{*}{$\begin{array}{l}\text { Rata- } \\
\text { rata } \\
(\%)\end{array}$} & \multicolumn{2}{|c|}{$\begin{array}{c}\text { Persentase Kesesuaian } \\
\text { (P) }\end{array}$} \\
\hline & & & & $\begin{array}{l}\text { Waktu } \\
\text { Ideal }\end{array}$ & Toleransi \\
\hline $\begin{array}{l}\text { Mendengar/memperhati } \\
\text { kan } \\
\text { guru/teman }\end{array}$ & 10,4 & 10,4 & 10,4 & $13 \%$ & $7 \% \leq \mathrm{P} \leq 18 \%$ \\
\hline $\begin{array}{l}\text { membaca/memahami } \\
\text { masalah di } \\
\text { LKS }\end{array}$ & 11,45 & 9,37 & 10,41 & $10 \%$ & $5 \% \leq \mathrm{P} \leq 15 \%$ \\
\hline $\begin{array}{l}\text { Menyelesaikan masalah } \\
\text { atau menemukan solusi } \\
\text { pemecahan masalah }\end{array}$ & 19,79 & 23,96 & 21,88 & $27 \%$ & $22 \% \leq P \leq 32 \%$ \\
\hline $\begin{array}{l}\text { Membandingkan hasil } \\
\text { temuan diskusi } \\
\text { kelompok dengan hasil } \\
\text { diskusi kelompoknya }\end{array}$ & 25 & 26,04 & 25,52 & $30 \%$ & $25 \% \leq P \leq 35 \%$ \\
\hline $\begin{array}{l}\text { Bertanya/menyampaikan } \\
\text { pendapat/ide kepada } \\
\text { guru } \\
\text { atau teman sekelompok }\end{array}$ & 12,5 & 12,5 & 12,5 & $10 \%$ & $5 \% \leq \mathrm{P} \leq 15 \%$ \\
\hline \begin{tabular}{lrr} 
Menarik & \multicolumn{2}{r}{ kesimpulan } \\
suatu konsep yang \\
ditemukan atau & suatu \\
prosedur & & yang \\
dikerjakan & & \\
\end{tabular} & 11,46 & 12,5 & 11,98 & $10 \%$ & $5 \% \leq \mathrm{P} \leq 15 \%$ \\
\hline $\begin{array}{l}\text { Perilaku yang tidak } \\
\text { relevan dengan KBM }\end{array}$ & 5,21 & 3,13 & 7,29 & $0 \%$ & $0 \% \leq P \leq 5 \%$ \\
\hline
\end{tabular}

Berdasarkan tabel di atas diketahui bahwa beberapa aktivitas siswa telah mengacu pada kriteria waktu ideal aktivitas siswa dalam pembelajaran. Kecuali aspek menyelesaikan masalah atau menemukan solusi pemecahan masalah dan aspek perilaku yang tidak relevan dengan KBM berada di luar toleransi waktu yang diberikan. Sehingga disimpulkan bahwa aktivitas siswa pada siklus I tidak aktif.

\section{Observasi Hasil Belajar Siswa Siklus I}

Tabel 3. Deskripsi Hasil Tes Siklus 1

\begin{tabular}{c|c|c|c|c}
\hline $\begin{array}{c}\text { Presentase } \\
\text { Pengusaan }\end{array}$ & $\begin{array}{c}\text { Tingkat } \\
\text { Kemampuan }\end{array}$ & $\begin{array}{c}\text { Banyak } \\
\text { Siswa }\end{array}$ & $\begin{array}{c}\text { Presentase } \\
\text { Jumlah } \\
\text { Siswa }\end{array}$ & $\begin{array}{c}\text { Rata-rata } \\
\text { Skor } \\
\text { Kemampuan }\end{array}$ \\
\cline { 1 - 3 } $90 \%-100 \%$ & Sangat tinggi & 4 & 18.18 & \multirow{2}{*}{69.09} \\
\hline $80 \%-89 \%$ & Tinggi & 3 & 13.64 & \\
\hline $70 \%-79 \%$ & Sedang & 5 & 22.73 & \\
\hline $60 \%-69 \%$ & Rendah & 3 & 13.64 & \\
\hline
\end{tabular}




\begin{tabular}{cl|c|c|c|c}
\hline \multirow{2}{*}{$0 \%-59 \%$} & $\begin{array}{c}\text { Sangat } \\
\text { rendah }\end{array}$ & 7 & 31.82 \\
\cline { 1 - 3 } & & 22 & $100 \%$ & \\
\hline
\end{tabular}

Dari hasil tes kemampuan pemecahan masalah 1 diperoleh peningkatan ketuntasan belajar sebesar 27,27\% yaitu dari $27,27 \%$ menjadi $54,55 \%$. Tingkat ketuntasan klasikal pada siklus 1 adalah $54,55 \%$ belum mencukupi syarat ketuntasan klasikal (85\%). Maka dilanjutkan ke siklus 2 dimana hasil tes siklus 1 ini dijadikan acuan dalam memberikan tindakan pada siklus 2 untuk mengatasi kesulitan belajar siswa sehingga dapat meningkatkan hasil belajar siswa.

\section{d. Tahap Refleksi}

Berdasarkan hasil diskusi, maka perlu diadakan perbaikanperbaikan yaitu sebagai berikut: (1) guru mengupayakan agar peserta didik aktif dalam kelompok, sehingga diskusi dapat berjalan dengan baik dan akan member pengarahan manfaat kerjasama dalam kelompok; (2) guru harus memberikan motivasi agar peserta didik mau berpendapat dan bertanya kepada guru maupun teman dalam kelompok; (3) guru akan lebih menyesuaikan waktu yang ada dan meminta peserta didik lebih menghargai dan memanfaatka waktu; (4) guru membuat strategi agar peserta didik mudah menerima pelajaran dengan waktu yang singkat; (5) karena ketuntasan pembelajaran belum tercapai maka harus dilaksanakan perbaikan pembelajaran. Oleh karena itu pembelajaran dilanjutkan ke siklus 2.

\section{Pelaksanaan Siklus 2}

\section{a. Tahap Perencanaan}

Peneliti membuat rencana tindakan 2 untuk mengatasi kekurangan dan kegagalan pembelajaran selama siklus 1 . Pada tahap ini rencana tindakan yang akan dilakukan yaitu (a) menyusun RPP dengan materi peningkatan segiempat dan segitiga dengan memperhatikan refleksi siklus l; (b) guru menyusun soal tes evaluasi 2; (c) guru mempersiapkan format wawancara; (d) guru mempersiapkan lembar observasi untuk mengamati keadaan siswa selama pembelajaran; (e) guru lebih memotivasi siswa agar berpartisipasi aktif dalam diskusi; dan (f) guru membimbing siswa dalam menjawab pertanyaan dari guru.

\section{b. Tahap Pelaksanaan}

Materi yang diajarkan adalah menjelaskan unsur-unsur dan sifat-sifat pada persegi panjang, persegi, segitiga, trapesium, jajar genjang, belah ketupat dan layang-layang dalam masalah nyata. Pembelajaran dimulai dengan apersepsi mengingatkan materi yang lalu dan memberikan motivasi kepada siswa dengan mengajukan pertanyaan yang menantang. Kemudian peneliti juga memberitahukan tujuan pembelajaran yang akan dipelajari yaitu tentang sifatsifat pada persegi panjang, persegi, segitiga, trapesium, jajar genjang, belah ketupat dan layang-layang. Serta menyampaikan langkah-langkah pembelajaran yang akan digunakan yaitu strategi pembelajaran jigsaw. 


\section{c. Tahap observasi}

1. Observasi aktivitas guru pada siklus II

Tabel 4. Observasi Aktivitas Guru siklus II

\begin{tabular}{|c|c|c|c|c|}
\hline NO & Aspek Yang Diamati & RPP & $\mathrm{RPP}$ & Rata- \\
\hline 1. & \multicolumn{4}{|l|}{ Pendahuluan: } \\
\hline & $\begin{array}{l}\text { d. Kemampuan memotivasi siswa/ mengkomunikasikan } \\
\text { tujuan pembelajaran }\end{array}$ & 4 & 5 & 4.5 \\
\hline & $\begin{array}{l}\text { e. Kemampuan menghubungkan pelajaran saat itu } \\
\text { dengan pelajaran sebelumnya atau membahas PR }\end{array}$ & 4 & 4 & 4 \\
\hline & $\begin{array}{l}\text { f. Kemampuan menginformasikan langkah-langkah } \\
\text { pembelajaran yang digunakan }\end{array}$ & 4 & 5 & 4,5 \\
\hline 2. & \multicolumn{4}{|l|}{ Kegiatan Inti: } \\
\hline & j. $\quad$ Kemampuan menjelaskan materi & 5 & 5 & 5 \\
\hline & $\begin{array}{l}\text { k. Kemampuan mengarahkan siswa untuk bekerja sama } \\
\text { dalam kelompok menemukan jawaban soal, dengan } \\
\text { memberikan bantuan terbatas }\end{array}$ & 4 & 4 & 4 \\
\hline & $\begin{array}{l}\text { 1. Kemampuan cara mengamati cara siswa } \\
\text { menyelesaikan soal/masalah }\end{array}$ & 4 & 5 & 4,5 \\
\hline & $\begin{array}{l}\text { m. Kemampuan mengoptimalkan interaksi siswa dalam } \\
\text { bekerja }\end{array}$ & 4 & 4 & 4 \\
\hline & $\begin{array}{l}\text { n. Kemampuan memimpin diskusi kelas/menguasai } \\
\text { kelas }\end{array}$ & 4 & 4 & 4 \\
\hline & $\begin{array}{l}\text { o. Kemampuan mendorong siswa untuk menanggapi } \\
\text { hasil presentasi kelompok lain }\end{array}$ & 4 & 5 & 4,5 \\
\hline & $\begin{array}{l}\text { p. Kemampuan mendorong siswa untuk mau bertanya, } \\
\text { mengeluarkan pendapat atau menjawab pertanyaan. }\end{array}$ & 4 & 4 & 4 \\
\hline & q. Kemampuan menghargai pendapat berbagai siswa & 4 & 4 & 4 \\
\hline & r. Kemampuan mengajukan dan menjawab pertanyaan & 4 & 4 & 4 \\
\hline \multirow[t]{4}{*}{3.} & \multicolumn{4}{|l|}{ Penutup: } \\
\hline & $\begin{array}{l}\text { b. Kemampuan mengarahkan siswa untuk menemukan } \\
\text { sendiri dan menarik kesimpulan } \\
\text { tentangkonsep/prinsip/defenisi/teorema/rumus/prose } \\
\text { dur matematika }\end{array}$ & 4 & 5 & 4,5 \\
\hline & $\begin{array}{l}\text { d. Kemampuan menegaskan hal-hal penting intisari } \\
\text { berkaitan dengan pembelajaran }\end{array}$ & 4 & 4 & 4 \\
\hline & $\begin{array}{l}\text { Kemampuan menyampaikan judul sub materi } \\
\text { berikutnya/memberikan PR kepada siswa/menutup }\end{array}$ & 4 & 5 & 4,5 \\
\hline
\end{tabular}




\begin{tabular}{c|l|c|c|c}
\hline & Pelajaran & & & \\
\hline 4. & Kemampuan Mengelola Kelas & 4 & 4 & 4 \\
\hline 5. & Suasana Kelas & 4 & 4 & 4 \\
\hline & c. Antusias siswa & 5 & 5 & 5 \\
\hline d. Antusias Guru & \multicolumn{4}{|c}{4,27} \\
\hline \multicolumn{2}{c|}{ Rata-rata Keseluruhan } & \multicolumn{4}{|c}{} \\
\hline
\end{tabular}

Kemampuan peneliti mengelola kelas juga menunjukkan peningkatan dengan nilai rata-rata 5. Suasana kelas terdiri dari aspek antusias siswa dan aspek antusias guru (peneliti). Untuk aspek antusias siswa mengalami peningkatan sebesar 0,5, sedangkan aspek antusias guru (peneliti) sudah muncul semua dari siklus sebelumnya. Secara keseluruhan aktivitas guru dalam mengelola pembelajaran pada siklus I adalah 4,86. Sesuai dengan taraf keberhasilan tindakan maka dapat disimpulkan bahwa pembelajaran pada siklus II sangat baik.

\section{Observasi aktivitas siswa siklus II}

Tabel 5. Observasi Aktivitas Siswa Siklus II

\begin{tabular}{|c|c|c|c|c|c|}
\hline \multirow{2}{*}{$\begin{array}{c}\text { Aspek Pengamatan } \\
\text { Aktivitas Siswa }\end{array}$} & \multirow{2}{*}{$\begin{array}{l}\text { RPP } \\
\text { III }\end{array}$} & \multirow{2}{*}{$\begin{array}{l}\text { RPP } \\
\text { IV }\end{array}$} & \multirow{2}{*}{$\begin{array}{l}\text { Rata- } \\
\text { rata } \\
(\%)\end{array}$} & \multicolumn{2}{|c|}{$\begin{array}{c}\text { Persentase Kesesuaian } \\
(\mathrm{P})\end{array}$} \\
\hline & & & & $\begin{array}{l}\text { Waktu } \\
\text { Ideal }\end{array}$ & Toleransi \\
\hline $\begin{array}{l}\text { Mendengar/memperhati } \\
\text { kan } \\
\text { guru/teman }\end{array}$ & 11,5 & 10,4 & 10,9 & $13 \%$ & $7 \% \leq \mathrm{P} \leq 18 \%$ \\
\hline $\begin{array}{l}\text { membaca/memahami } \\
\text { masalah kontekstual di } \\
\text { LKS }\end{array}$ & 13,54 & 13,54 & 13,54 & $10 \%$ & $5 \% \leq P \leq 15 \%$ \\
\hline $\begin{array}{l}\text { Menyelesaikan masalah } \\
\text { atau menemukan solusi } \\
\text { pemecahan masalah }\end{array}$ & 25 & 25 & 25 & $27 \%$ & $22 \% \leq P \leq 32 \%$ \\
\hline $\begin{array}{l}\text { Membandingkan hasil } \\
\text { temuan diskusi } \\
\text { kelompok dengan hasil } \\
\text { diskusi } \\
\text { kelompoknya }\end{array}$ & 25 & 29,17 & 27,08 & $30 \%$ & $25 \% \leq P \leq 35 \%$ \\
\hline $\begin{array}{l}\text { Bertanya/menyampaikan } \\
\text { pendapat/ide kepada } \\
\text { guru } \\
\text { atau teman sekelompok }\end{array}$ & 11,46 & 9,37 & 10,42 & $10 \%$ & $5 \% \leq P \leq 15 \%$ \\
\hline $\begin{array}{l}\text { Menarik kesimpulan } \\
\text { suatu } \\
\text { konsep yang ditemukan } \\
\text { atau suatu prosedur yang }\end{array}$ & 10,42 & 11,46 & 10,94 & $10 \%$ & $5 \% \leq \mathrm{P} \leq 15 \%$ \\
\hline
\end{tabular}




\begin{tabular}{l|l|l|l|l|l}
\hline dikerjakan & & & & & \\
\hline $\begin{array}{l}\text { Perilaku yang tidak } \\
\text { relevan dengan KBM }\end{array}$ & 3,13 & 1,04 & 2,08 & $0 \%$ & $0 \% \leq \mathrm{P} \leq 5 \%$ \\
\hline
\end{tabular}

Berdasarkan hasil pengamatan di lapangan di atas diketahui bahwa aktivitas siswa semua telah mengacu pada kriteria waktu ideal aktivitas siswa dalam pembelajaran. Secara umum dapat disimpulkan bahwa aktivitas siswa selama mengikuti pembelajaran dengan menggunakan strategi pembelajaran jigsaw pada materi segiempat dan segitiga sudah aktif.

\section{Observasi hasil belajar siswa siklus II}

Tabel 6. Deskripsi Hasil Tes Siklus 2

\begin{tabular}{c|c|c|c|c}
\hline $\begin{array}{c}\text { Presentase } \\
\text { Pengusaan }\end{array}$ & $\begin{array}{c}\text { Tingkat } \\
\text { Kemampuan }\end{array}$ & $\begin{array}{c}\text { Banyak } \\
\text { Siswa }\end{array}$ & $\begin{array}{c}\text { Presentase } \\
\text { Jumlah } \\
\text { Siswa }\end{array}$ & $\begin{array}{c}\text { Rata-rata } \\
\text { Skor } \\
\text { Kemampuan }\end{array}$ \\
\cline { 1 - 3 } $90 \%-100 \%$ & Sangat tinggi & 5 & 22.73 & \\
\cline { 1 - 3 } $80 \%-89 \%$ & Tinggi & 8 & 36.36 & \multirow{2}{*}{79.77} \\
\cline { 1 - 3 } $70 \%-79 \%$ & Sedang & 6 & 27.27 & \\
\cline { 1 - 3 } $60 \%-69 \%$ & Rendah & 3 & 13.64 & \\
\cline { 1 - 3 } $0 \%-59 \%$ & Sangat rendah & 0 & 0.00 & \\
\hline \multicolumn{2}{c|}{$\Sigma$} & 22 & $100 \%$ & \\
\hline
\end{tabular}

\section{d. Tahap Refleksi}

Berdasarkan hasil observasi, wawancara, dan dari data tes siklus 2, berikut ini diuraikan keberhasilan dan kegagalan dalam pelaksanaan tindakan pada siklus 2, yaitu: (1) Dari hasil tes yang dilakukan pada siklus 2, siswa yang tuntas belajar 19 siswa (86,36\%), sedangkan yang tidak tuntas 3 siswa (13,64\%) dengan rata-rata kelas 79,77 sehingga ketuntasan belajar sudah tercapai; dan (2) Terdapat peningkatan pada keaktifan siswa dan pertukaran pengetahuan antar siswa. Hal ini berdasarkan hasil observasi terhadap aktivitas siswa selama pembelajaran berlangsung, dari 54,55\% pada siklus 1 menjadi 86,36\% pada siklus 2. Pelaksanaan pada siklus 2 ini, secara garis besar berlangsung baik. Karena ketuntasan belajar klasikal sudah tercapai maka pembelajaran dengan strategi pembelajaran jigsaw berhenti. Dengan demikian diperoleh bahwa pembelajaran dengan Strategi pembelajaran jigsaw berhenti mampu meningkatkan hasil belajar matimatika siswa. Hal ini tampak dari analisis hasil tes setelah akhir pelaksanaan siklus 2. Ketuntasan belajar klasikal pada siklus 1 54,55\% meningkat menjadi $86,36 \%$ pada siklus 2, dan ketuntasan belajar klasikal (85\%) sudah tercapai.

\section{E. Pembahasan}

Penerapan strategi pembelajaran aktif berhenti dapat meningkatkan hasil belajar matematika siswa. Berdasarkan hasil penelitian, sebelum diberi tindakan persentase ketuntasan klasikal 27,27\% pada tes awal. Hal ini dipengaruhi oleh belum ada materi yang diajarkan oleh siswa, sebab tes awal diberikan sebelum pembelajaran dimulai. Setelah diberikan tindakan 1 dengan menggunakan strategi pembelajaran aktif berhenti persentase ketuntasan klasikal meningkat menjadi 
54,55\% dari tes awal. Namun ketuntasan klasikal belum terpenuhi. Hal ini dipengaruhi oleh siswa yang kurang memahami materi yang diajarkan, dan sebagian siswa tidak berpartisipasi aktif dalam diskusi mereka. Banyak siswa yang masih kesulitan untuk menyelesaikan tugas dan saling bertukar pengetahuan dan masih banyak siswa merasa kebingungan dengan contoh yang guru berikan. Bedasarkan kelemahan-kelemahan yang ditemukan dalam siklus 1 , maka guru merencanakan pengajaran yang lebih baik dan lebih memberikan motivasi dan bimbingan untuk dilaksanakan pada siklus 2. Kemudian dilaksanakan pemberian tindakan siklus 2, tetap dengan strategi pembelajaran jigsaw berhenti diperoleh presentase ketuntasan klasikal 86,36\% yang berarti telah mengalami peningkatan sebesar $31,82 \%$ dari tes 1 . Peningkatan presentase ketuntasan klasikal siklus 2 karena kendala yang ditemukan pada siklus 1 telah diatasi dengan baik. Hal ini dilihat dari banyaknya siswa yang sudah memahami maksud dari contoh yang guru berikan. Siswa berpartisipasi aktif, saling bertukar ide dan pengetahuan, dan bersama-sama menyelesaikan tugas yang diberikan.

Penerapan strategi pembelajaran jigsaw merupakan pembelajaran dimana siswa dituntut untuk lebih aktif dalam pengetahuannya tentang matematika sesuai dengan kemampuan masing-masing sehingga akibatnya memberikan hasil belajar yang lebih baik pada siswa. Dari hasil penelitian diperoleh beberapa hal yang menjadi kendala dalam pembelajaran dengan strategi pembelajaran aktif ,diantarnya masih ada siswa yang terlihat tidak antusias mengerjakan soal-soal, dan tidak berdiskusi dengan baik, beberapa siswa belum memahami materi Segi empat dan segi tiga sehingga mengalami kesulitan dalam diskusi.

\section{F. Kesimpulan}

Hasil penelitian dari penggunaan strategi pembelajaran jigsaw pada mata pelajaran matematika Kelas VII-2 MTsN 2 Bireuen dapat disimpulkan bahwa adanya peningkatan hasil belajar siswa. Peningkatan ini dapat dilihat dari nilai rata-rata kelas mengalami peningkatan. Hal ini dapat ditunjukkan dari hasil evaluasi yang telah dilaksanakan terdapat peningkatan hasil belajar siswa yang semula nilai rata-rata 57,73 sebelum tindakan dan pada siklus I meningkat menjadi 69,09. Sedangkan pada siklus II peningkatan hasil belajar menjadi 79,77. Ini menunjukkan $86,36 \%$ siswa berhasil dalam belajar matematika dengan penggunaan strategi pembelajaran jigsaw.

\section{BIBLIOGRAFI}

Abin, Syamsudin. (1996). Psikologi Kependidikan. Bandung: Remaja Rosda Karya. Abdurrahman, Mulyono. (1999). Pendidikan Bagi Anak Berkesulitan Belajar. Jakarta: Rineka Cipta.

A. Suhaenah Suparno. (2001). Membangun Kompetensi Belajar. Direktorat Jendral Pendidikan Tinggi Departemen Pendidikan Nasional.

Asrori, Mohammad. (2008). Psikologi Pembelajaran, Bandung: Wacana Prima

Endrayanto, Herman, dkk., (2014). Penilaian Belajar Siswa di Sekolah. Yogyakarta: Kanisius

Hamalik, Oemar. (2007). Kurikulum dan Pembelajaran. Jakarta: Bumi Aksara 
Isjoni, 2009. Pembelajaran Kooperatif Meningkatkan Kecerdasan Komunikasi Antar Peserta Didik, Yogyakarta: Pustaka Pelajar

Miftahul Huda, (2011). Kooperatif Learning (Strategi, Teknik, Struktue, dan Strategi Penerapan)' Yogyakarta: Pustaka Pelajar

Nasution, S. (2000), Didaktif Asas-asas Mengajar, Jakarta: Bumi Aksara

Slameto. (2010). Belajar dan Faktor-faktor yang Mempengaruhinya. Jakarta: Rineka Cipta.

Suharsimi, Arikunto. (2013). Dasar-dasar Evaluasi Pendidikan. Jakarta: Bumi Aksara.

Susanto, Ahmad. (2013). Teori Belajar dan Pembelajaran di Sekolah Dasar. Jakarta: Kencana.

Suyitno, Amin. (2006). Dasar-Dasar dan Proses Pembelajaran Matematika. Semarang: FMIPA UNNES

Trianto, (2010). Mendesain Model Pembelajaran Inovatif-Progresif, Jakarta: Kencana Prenada Media Group

Undang-undang No. 20 tahun. (2003). Tentang Sistem Pendidikan Nasional dan Penjelasannya. Yogyakarta: Media Wacana Pres. 